\title{
First molecular phylogenetic insights into the evolution of Eriocaulon (Eriocaulaceae, Poales)
}

\author{
Isabel Larridon ${ }^{1}(1) \cdot$ Norio Tanaka ${ }^{2} \cdot$ Yuxi Liang ${ }^{1} \cdot$ Sylvia M. Phillips ${ }^{1} \cdot$ Anders S. Barfod $^{3} \cdot$ Seong-Hyun Cho ${ }^{4}$. \\ Stephan W. Gale ${ }^{5}$ Richard W. Jobson ${ }^{6} \cdot$ Young-Dong Kim $^{4} \cdot \mathrm{Jie} \mathrm{Li}^{7} \cdot$ A. Muthama Muasya ${ }^{8} \cdot$ John A. N. Parnell $^{9}$. \\ Amornrat Prajaksood ${ }^{10} \cdot$ Kohtaroh Shutoh $^{11} \cdot$ Phetlasy Souladeth $^{12} \cdot$ Shuichiro Tagane $^{13} \cdot$ Nobuyuki Tanaka $^{2}$. \\ Okihito Yano ${ }^{14} \cdot$ Attila Mesterházy $^{15} \cdot$ Mark F. Newman $^{16} \cdot$ Yu Ito $^{17}$
}

Received: 4 March 2019 / Accepted: 29 July 2019 / Published online: 5 August 2019

(c) The Author(s) 2019

\begin{abstract}
Eriocaulon is a genus of c. 470 aquatic and wetland species of the monocot plant family Eriocaulaceae. It is widely distributed in Africa, Asia and America, with centres of species richness in the tropics. Most species of Eriocaulon grow in wetlands although some inhabit shallow rivers and streams with an apparent adaptive morphology of elongated submerged stems. In a previous molecular phylogenetic hypothesis, Eriocaulon was recovered as sister of the African endemic genus Mesanthemum. Several regional infrageneric classifications have been proposed for Eriocaulon. This study aims to critically assess the existing infrageneric classifications through phylogenetic reconstruction of infrageneric relationships, based on DNA sequence data of four chloroplast markers and one nuclear marker. There is little congruence between our molecular results and previous morphology-based infrageneric classifications. However, some similarities can be found, including Fyson's sect. Leucantherae and Zhang's sect. Apoda. Further phylogenetic studies, particularly focusing on less well sampled regions such as the Neotropics, will help provide a more global overview of the relationships in Eriocaulon and may enable suggesting the first global infrageneric classification.
\end{abstract}

Keywords Aquatic plants $\cdot$ Eriocaulaceae $\cdot$ Evolution $\cdot$ Molecular phylogenetics $\cdot$ Monocots

\section{Introduction}

Eriocaulon L., commonly known as pipeworts, is a cosmopolitan genus of ephemeral and perennial aquatic and wetland plants of the Eriocaulaceae family (Poales). The genus includes c. 470 species (WCSP 2019) and is most speciesrich in Asia (c. 220 species), the Americas (c. 122 species) and Africa (c. 111 species), with its centres of diversity in the tropics (Stützel 1998). Species of Eriocaulon primarily grow in seasonal or permanent wetlands while some inhabit shallow rivers and streams with an apparent adaptive morphology of elongated submerged stems. Two subfamilies are recognised in Eriocaulaceae, i.e. Eriocauloideae with

Electronic supplementary material The online version of this article (https://doi.org/10.1007/s10265-019-01129-3) contains supplementary material, which is available to authorized users.

Isabel Larridon

i.larridon@kew.org

Extended author information available on the last page of the article diplostemonous flowers and glandular petals, and Paepalanthoideae with isostemonous flowers and eglandular petals (Giulietti et al. 2012; Ruhland 1903). Together with the African genus Mesanthemum Körn., which was recently revised by Liang et al. (2019), Eriocaulon is placed in subfamily Eriocauloideae. Subfamily Paepalanthoideae is largely restricted to the Americas.

Despite the ecological importance of Eriocaulon as a species-rich genus of wetland plants, no attempts have been made to reconstruct a molecular phylogeny for the genus. Only a few Eriocaulon species have been included in the sampling of family level studies (e.g. de Andrade et al. 2010; Giulietti et al. 2012). A molecular phylogenetic study including a broad sampling covering much of the taxonomic, morphological and geographic variation within the genus is needed to assess whether the infrageneric taxa suggested in the existing regional infrageneric classifications of Eriocaulon circumscribe monophyletic groups. It is a first step in providing insights into the evolution of the genus and to 
enable establishing a new infrageneric classification for the whole genus in the future.

Several regional infrageneric classifications of the species of Eriocaulon have been proposed. Mueller (1859) established two sections to accommodate the then known Australian species of Eriocaulon, i.e. sect. Dimorphogyne F. Muell. to accommodate E. heterogynum F. Muell. and sect. Eriocaulon L. was established as autonym to place the remaining six Australian species (Table S1).

Fyson $(1919,1921,1922)$ established an infrageneric classification for the Indian species of Eriocaulon, placing 51 species in eight named sections (Table S1). Later, Ansari and Balakrishnan $(1994,2009)$ proposed an infrageneric classification of twelve numbered sections (I-XII) for the Indian species of Eriocaulon (Table S1). There is little overlap between these two classification systems for India, although both Fyson $(1919,1921,1922)$ and Ansari and Balakrishnan $(1994,2009)$ place E. alpestre Hook.f. \& Thomson ex Körn. in a monotypic section (i.e. sect. ComatoSepalae Fyson and sect. I; Table S1). Also, species of sect. Hirsutae Fyson appear to be mostly placed in sect. II and III by Ansari and Balakrishnan (1994, 2009), while species of sect. Leucantherae Fyson appear to be placed in sect. XII.

Ma (1991) classified the Chinese species of Eriocaulon into subgen. Trimeranthus Nakai (27 species) and subgen. Eriocaulon sensu Nakai (monotypic: E. decemflorum Maxim.). He further divided subgen. Trimeranthus into three sections: sect. Macrocaulon Ruhl. (16 species); sect. Leucocephala Nakai (three species); and sect. Spathopeplus Nakai (eight species). Eriocaulon sect. Macrocaulon comprised ser. Tmetopsis Ruhl. (11 species) and ser. Leiantha W.L.Ma (4 species), while sect. Spathopeplus consisted of ser. Miqueliana Satake (2 species), ser. Robustiora W.L.Ma (4 species), and ser. Manshanensia W.L.Ma (2 species) (Ma 1991) (Table S1). Later Ma (1997) added sect. Macrocaulon ser. Disepala Satake to retrieve E. merrillii Ruhl. and E. sclerophyllum W.L.Ma from ser. Leiantha (Table S1). The numbers of species classified were 32 in Ma (1997) compared to Ma (1991) who accepted 28 species. Ma et al. (2000) accepted 35 species in China and rejected all infrageneric classifications.

Zhang (1999) proposed an infrageneric classification which placed 71 East Asian species in two subgenera and 10 sections (Table $\mathrm{S} 1$ ), recognising some of the sections used by Fyson $(1919,1921,1922)$ and Ma $(1991,1997)$ together with some additional sections. There is little overlap between the classifications of Zhang (1999) and Ansari and Balakrishnan (1994, 2009). However, E. hamiltonianum Mart. and E. truncatum Buch.-Ham. ex Mart. are grouped in sect. VII in Ansari and Balakrishnan $(1994,2009)$ and sect. Disepala in Zhang (1999).

None of the published regional infrageneric classifications have yet been scrutinised using molecular phylogenetic data. A molecular study by de Andrade et al. (2010) on Eriocaulaceae included just five species of Eriocaulon while the study of Giulietti et al. (2012) included just four species. Of the species sequenced in these studies, E. cinereum $\mathrm{R} . \mathrm{Br}$. is the only one that has been included in the published infrageneric classifications. The objectives of this study are to: (1) construct a molecular phylogeny of Eriocaulon, and (2) critically assess the existing regional infrageneric classifications of Eriocaulon.

\section{Materials and methods}

\section{Taxon sampling}

Samples of Eriocaulon were collected in the field or obtained from herbarium specimens (Table S2). The following regional treatments were used for specimen identifications because no comprehensive global revision has been published: Cook (1996) and Ansari and Balakrishnan (2009) for India; Prajaksood et al. (2017) for Thailand; Ma et al. (2000) for China; Miyamoto (2015) for Japan; Bentham (1878) and Leach $(1992,2000,2017)$ for Australia; Cook (2004) for southern Africa; Meikle (1968) for west tropical Africa; Phillips (1998, 2010, 2011) for east and southern tropical Africa. Cook (1996), Ma $(1991,1997)$ and Ma et al. (2000) were referred to identify Indo-Burma specimens. The recently described species E. petraeum S.M.Phillips \& Burgt and E. sulanum S.M.Phillips \& Burgt (Phillips et al. 2012) were sampled. Our sampling included 199 accessions (116 from Asia; 59 from Africa; 14 from America; ten from Australia) from 79 ingroup species representing $16.8 \%$ of species diversity of the genus Eriocaulon (Fig. 1; Table S2). Xyris Gronov. of Xyridaceae and Mesanthemum, Syngonanthus Ruhl. and Tonina Aubl. of Eriocaulaceae, were chosen as outgroup taxa following de Andrade et al. (2010).

\section{DNA extraction, amplification and sequencing}

Total genomic DNA was extracted from silica gel-dried leaf tissues using the CTAB method described in Ito et al. (2010). Four regions of chloroplast DNA (ptDNA), i.e. mat $K, r b c L$, $r p o B$ and $r p o C l$ were PCR amplified with the following primers: matK-390F (Cuénoud et al. 2002) and matK-1520R (Whitten et al. 2000) for $m a t K$; rbcL-F1F (Wolf et al. 1994) and rbcL-1379R (Little and Barrington 2003) for $r b c L$; " $2 \mathrm{f}$ " and " $4 \mathrm{r}$ " for $r p o B$ (Royal Botanic Gardens, Kew); and "1f" and "3r" for rpoCl (Royal Botanic Gardens, Kew). The PCR amplification was conducted using TaKaRa Ex Taq polymerase (TaKaRa Bio, Shiga, Japan), and PCR cycling conditions were $94{ }^{\circ} \mathrm{C}$ for $60 \mathrm{~s}$; then 30 cycles of $94{ }^{\circ} \mathrm{C}$ for $45 \mathrm{~s}, 52{ }^{\circ} \mathrm{C}$ for $30 \mathrm{~s}, 72{ }^{\circ} \mathrm{C}$ for $60 \mathrm{~s}$; and finally, $72{ }^{\circ} \mathrm{C}$ for $5 \mathrm{~min}$. 


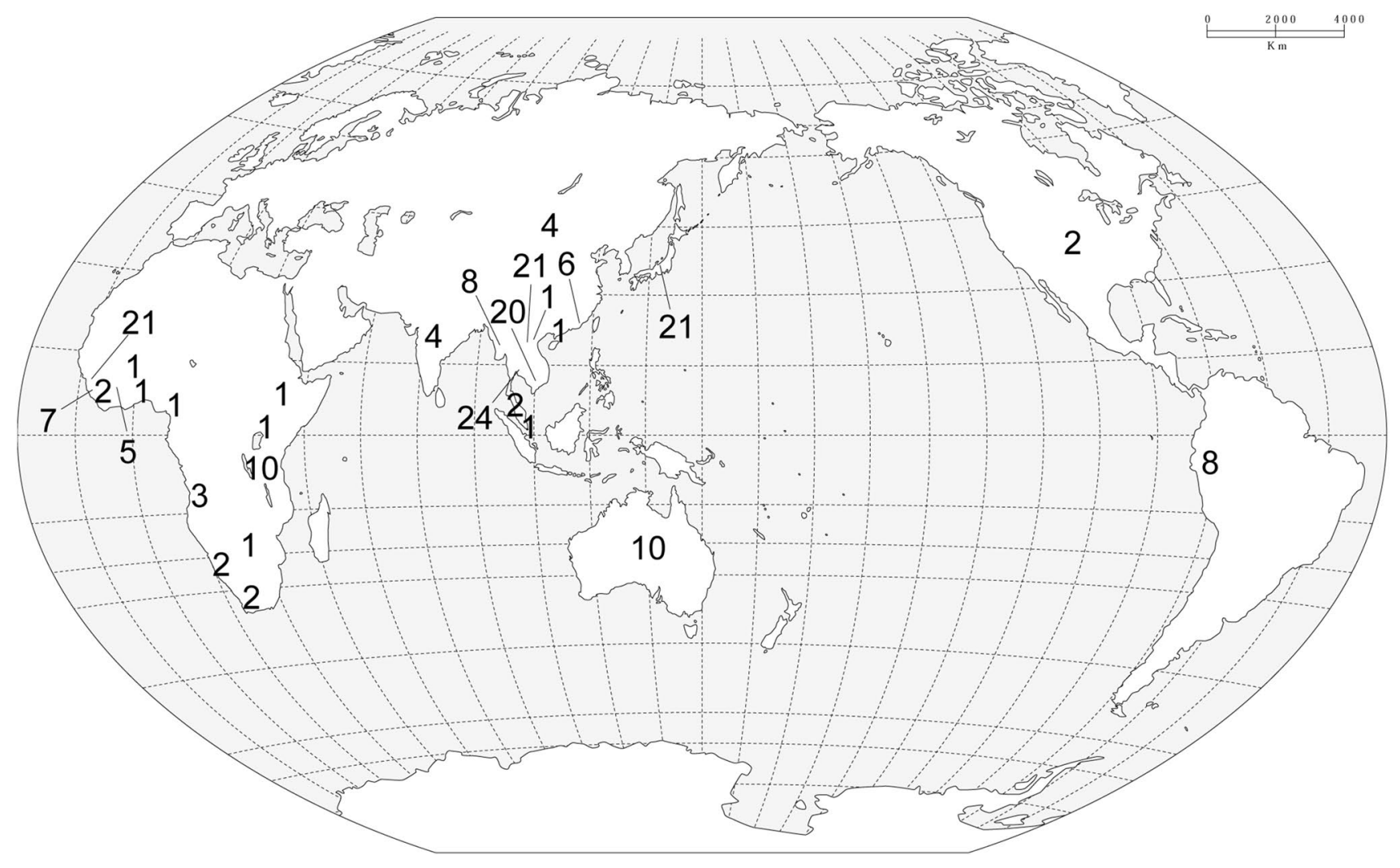

Fig. 1 Map of sampling localities of Eriocaulon species included in this study indicating the number of accessions sampled at each location

The PHYC gene (a distinct member of the phytochrome gene family) was selected as a nuclear marker, based on its phylogenetic utility as a single or low copy nuclear locus (Mathews and Donoghue 1999; Samuel et al. 2005). Fragments of a part of exon 1 of PHYC were amplified by PCR using Comm_PHYC_P1F (Hertweck et al. 2015) and the newly designed AlisPHYC-1R (5'-GCATCCATTTCMACA TCYTCCCA). The PCR cycling conditions were $94{ }^{\circ} \mathrm{C}$ for $90 \mathrm{~s}$; then 35 cycles of $94{ }^{\circ} \mathrm{C}$ for $45 \mathrm{~s}, 60{ }^{\circ} \mathrm{C}$ for $30 \mathrm{~s}$, $72{ }^{\circ} \mathrm{C}$ for $90 \mathrm{~s}$; and finally, $72{ }^{\circ} \mathrm{C}$ for $10 \mathrm{~min}$. The fragments obtained were digested with ExoSAP-IT and directly sequenced.

The PCR products were cleaned using ExoSAP-IT (GE Healthcare, Piscataway, NJ, USA) purification, and then amplified using ABI PRISM Big Dye Terminator v.3.1 (Applied Biosystems, Foster City, CA, USA) using the same primers as those used for the PCR amplifications. DNA sequencing was performed with an ABI PRISM 377 DNA sequencer (Applied Biosystems). Automatic base-calling was checked by eye in Genetyx-Win v.3 (Software Development Co., Tokyo, Japan). All sequences generated in the present study have been submitted to the DNA Data Bank of Japan (DDBJ), which is linked to GenBank, and their accession numbers and voucher specimen information are presented in Table S2.

\section{Molecular phylogenetic analyses}

Sequences were aligned using MAFFT v.7.058 (Katoh and Standley 2013) and then inspected manually. Analyses were independently performed for ptDNA ( $m a t K, r b c L$, $r p o B, r p o C 1)$ and PHYC datasets respectively to identify possible incongruences between different genomic regions. All 199 ingroup and the 13 outgroup accessions were represented in the ptDNA dataset, while 55 ingroup and five outgroup accessions were represented in the PHYC dataset. The ptDNA dataset consisted of concatenated gene alignments with 145 or $68 \%$ of accessions represented for mat $K, 197$ or $93 \%$ for $r b c L, 122$ or $58 \%$ for $r p o B$ and 41 or $19 \%$ for rpoCl.

Phylogenies were reconstructed using maximum parsimony (MP), maximum likelihood (ML), and Bayesian inference (BI; Yang and Rannala 1997). In the MP analysis in PAUP* v.4.0b10 (Swofford 2002), a heuristic search was performed with 100 random addition replicates with treebisection-reconnection (TBR) branch swapping, with the MulTrees option in effect. The MaxTrees option was set at 100,000. Bootstrap analyses (Felsenstein 1985) were performed using 1,000 replicates with TBR branch swapping and simple addition sequences. The MaxTrees option was set at 1,000 to avoid entrapment in local optima. 
For the ML analysis, the RAxML BlackBox online server (https://www.raxml-ng.vital-it.ch/) was used, which supports GTR-based models of nucleotide substitution (Stamatakis 2006). The maximum likelihood search option was used to find the best-scoring tree after bootstrapping. The gamma model of rate heterogeneity was selected. Statistical support for branches was calculated by rapid bootstrap analyses of 100 replicates (Stamatakis et al. 2008).

BI analyses were conducted with MrBayes v.3.2.2 (Ronquist and Huelsenbeck 2003; Ronquist et al. 2012) run on the CIPRES portal (Miller et al. 2010) after the best models had been determined in MrModeltest v.3.7 (Nylander 2002); these models were $\mathrm{GTR}+\mathrm{I}+\mathrm{G}$ and $\mathrm{GTR}+\mathrm{G}$ for ptDNA and PHYC datasets, respectively. Analyses were run for 6,335,000 and 1,500,000 generations for ptDNA and PHYC datasets, respectively, until the average standard deviation of split frequencies dropped below 0.01 , sampling every 1,000 generations and discarding the first $25 \%$ as burn-in. The convergence and effective sampling sizes (ESS) of all parameters were checked in Tracer v.1.6 (Rambaut et al. 2014). All trees were visualized using FigTree v.1.3.1 (Rambaut 2009). Support values are provided at the nodes [MP bootstrap support (BS), ML BS, BI posterior probability (PP)].

\section{Molecular dating}

A species tree was used to conduct a molecular dating analysis. A multispecies coalescent method (Heled and Drummond 2009) implemented in BEAST v.1.7.2 (Drummond et al. 2006; Drummond and Rambaut 2007) was performed to reconstruct a species tree. *BEAST was run using a multilocus dataset (ptDNA and PHYC) utilising all 212 ingroup and outgroup samples assigned to the 84 operational taxonomic units (OTUs) that were retrieved as clades in the phylogenetic analyses above. For the purposes of this analysis, species resolved as non-monophyletic or that contained multiple lineages are represented multiple times in the resulting tree (i.e. E. cinereum R.Br., E. latifolium Sm., E. nepalense J.D.Prescott ex Bong., E. plumale N.E.Br. and E. setaceum L.).

A relaxed molecular clock as implemented in BEAST v.2.4.4 (Drummond et al. 2006) was used and run on the CIPRES portal (Miller et al. 2010). Uncorrelated lognormal distributed substitution rates for each branch were used. The tree was rooted by constraining Eriocaulaceae. Previous divergence time estimates between Eriocaulaceae and Xyridaceae of 105 mya (million years ago) provided by Janssen and Bremer (2004), Bouchenak-Khelladi et al. (2014) and Hertweck et al. (2015) were used as a calibration point. These dates were set as a mean age with stdev $=0.1$ and a normal distribution. A Yule speciation process was used as tree prior. The default settings of
BEAUti v.2.4.4 were used for the other parameters. Two runs of ten million generations of the MCMC chains were run, sampling every 1,000 generations. Convergence of the stationary distribution was checked by visual inspection of plotted posterior estimates using Tracer v.1.6 (Rambaut et al. 2014). After discarding the first 1,000 trees as burnin, the samples were summarised in the maximum clade credibility tree using TreeAnnotator v.1.6.1 (Drummond and Rambaut 2007) with a posterior probability (PP) limit of 0.5 and summarizing mean node heights. The results were visualised using FigTree v.1.3.1 (Rambaut 2009).

\section{Results}

\section{Molecular phylogeny}

The ptDNA dataset for four genes included 4,445 aligned characters, of which 889 were parsimony informative. Analysis of this dataset yielded the imposed limit of 100,000 MP trees (tree length =2,590 steps; consistency index $=0.64$; retention index $=0.88$ ). The strict-consensus MP tree, the RAxML tree, and the MrBayes BI 50\% consensus tree showed no incongruent phylogenetic relationships; thus only the BI tree is presented here (Fig. 2a). Eriocaulon is broadly divided into two lineages: clade I and clades II-XII. The clade II is resolved as sister to clades III-XI. Clade III is resolved as sister to clades IV-XII. The relationships among clades IV-XII are less well resolved, except the weakly supported clades VIII-IX, yet each clade is highly supported. Singleton $\mathrm{X}$ is differentiated from clades XI-XII.

The PHYC dataset included 979 aligned characters, of which 324 were parsimony informative. Analysis of this dataset yielded the imposed limit of 100,000 MP trees (tree length $=1,181$ steps; consistency index $=0.53$; retention index $=0.81$ ). The strict-consensus MP tree, the RAxML tree and the MrBayes BI 50\% consensus tree showed no incongruent phylogenetic relationships; thus, only the BI tree is presented here (Fig. 2b). The labelling of PHYC tree follows the ptDNA tree. Eriocaulon is broadly divided into two lineages: Clade I and clades/singletons II-III, $\mathrm{V}-\mathrm{IX}$ and XI-XII. Singleton III is resolved as sister to clades/singletons II-XII. Singleton VI and clade VII are retrieved as sister lineages, as are clades/singletons II, V, VIII-IX and XI-XII. The relationships in the latter group are less resolved. Clade II is strongly supported. Clade XII plus Eriocaulon_schimperi_K3065 which belongs to clade XI in the ptDNA analysis are strongly supported as a natural group. Members of clade XI except Eriocaulon_schimperi_K3065 are retrieved as a clade. 
Fig. 2 MrBayes trees of Eriocaulon based on: a concatenated plastid DNA and $\mathbf{b}$ nuclear PHYC datasets. Samples collected in this study are associated with the specified vouchers. Branch lengths are proportional to the number of substitutions per site as measured by the scale bar. Values above the branches represent the maximum parsimony and maximum likelihood bootstrap support values (MP BS/ML BS), and Bayesian posterior probabilities (PP). BS $<70 \%$ and $\mathrm{PP}<0.9$ are indicated by hyphens while those of $\geq 90 \%$ and $\geq 0.95$ are shown as asterisks. Well-supported clades are highlighted by gray rectangles

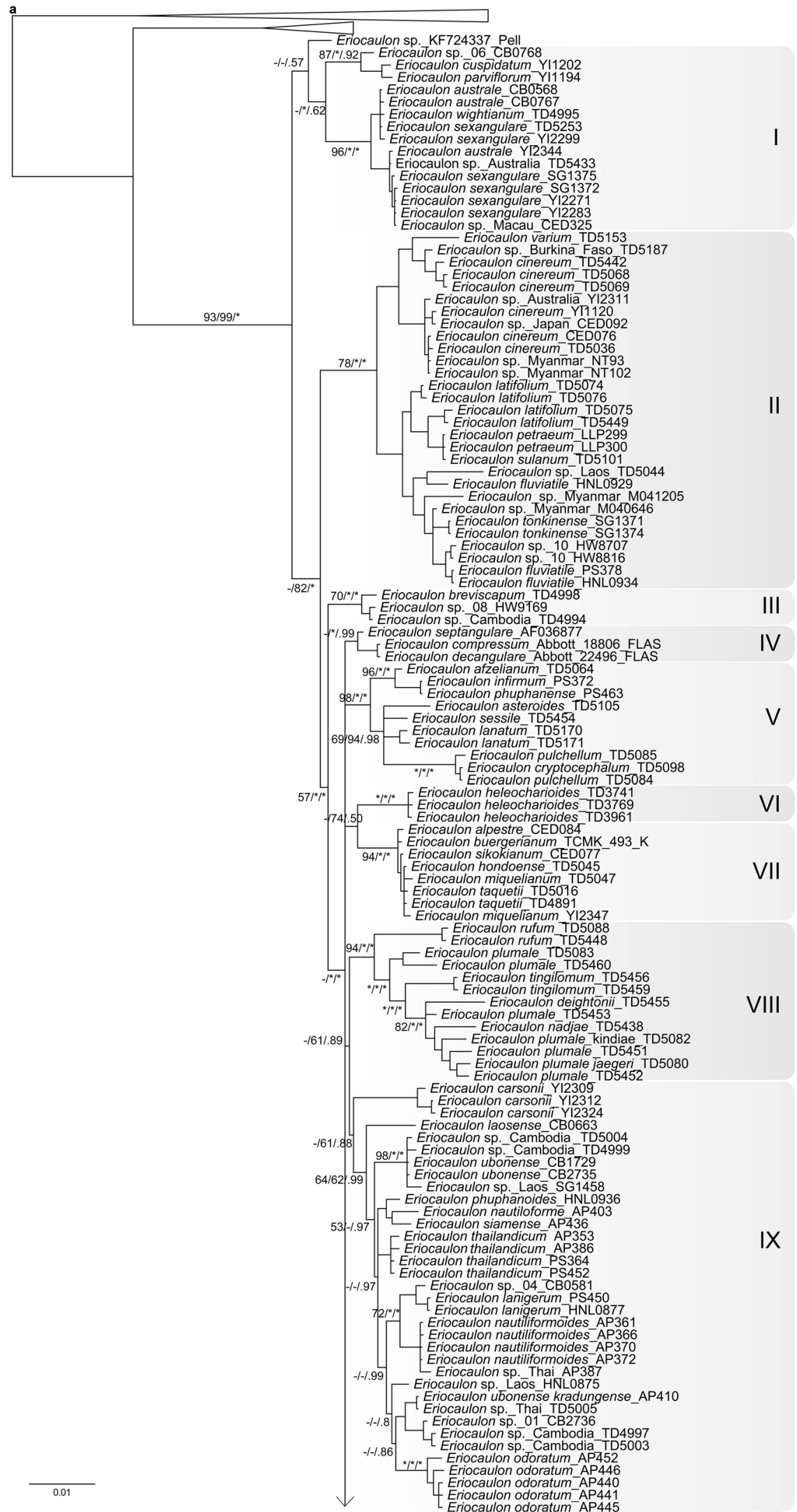


Fig. 2 (continued)

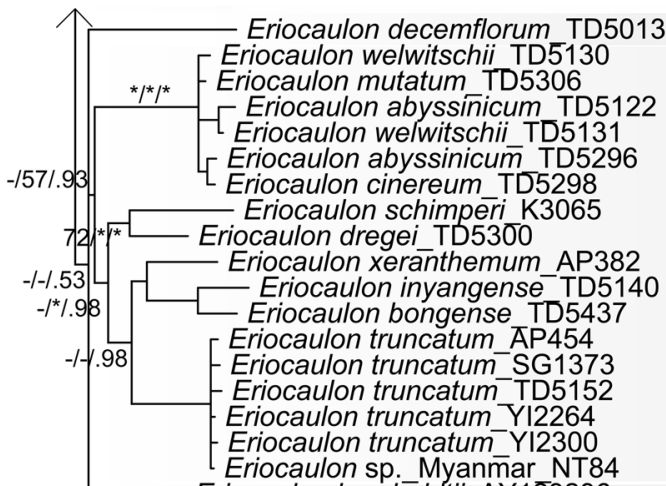

Eriocaulon humboldtii AY123236

Eriocaulon setaceum KP083049 Faden

Eriocaulon sp. Myanmar M021704
- Eriocaulon teucszii_TD5172

- Eriocaulon laniceps TD5141
Eriocaulon laniceps TD5142

Eriocaulon microcephalum TD5189

Eriocaulon microcephalum

-/95/.52 $\quad$ - Eriocaulon microcephalum L10252

Eriocaulon sp. Ecuador TD5197

Eriocaulon sp. -Ecuador -TD5205

Eriocaulon sp.-Ecuador-TD5206

Eriocaulon sp. Ecuador-TD5216

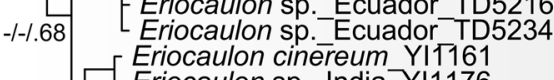

Eriocaulon sp. India YI1176

Eriocaulon siamenense AP429

[ Eriocaulon siamense_AP420

[ Eriocaulon siamense_AP420

Eriocaulon crassiusculum TD5136

Eriocaulon deightonii TD5093

-I-I.78 - Eriocaulon maronderanum TD5160

Eriocaulon nigericum TD5079

-161.71 - Eriocaulon remotum_TD5087

Eriocaulon transvaalicum dembianense_TD5119

- Eriocaulon porembskii TD5458

$60 / * /{ }^{*}$ [ Eriocaulon burttii TD5134

Eriocaulon mutâtum angustisepalum TD5125

- Eriocaulon transvaalicum hanningtonii_TD5092

69 Eriocaulon zollingerianum HNL0878

-1691.85 - Eriocaulon echinulatum CB0592

Eriocaulon echinulatum PS365

Eriocaulon echinulatum PS447

-l-1.59 [ Eriocaulon hamiltonianum AP405

4 Eriocaulon sp._Laos_SG1555

Eriocaulon sp. Myanmar NT101

Eriocaulon nepalense M040640

- Eriocaulon nepalense- TD5014

- Eriocaulon nepalense-TD5015

Eriocaulon parvum TD1324

Eriocaulon setaceúm TD5089

Eriocaulon parnellii AP415

Eriocaulon setaceum AP419

Eriocaulon napalense luzulifolium AP451

-1-1.94 - Eriocaulon setaceum HNL0933

Eriocaulon alpestre PI2242

Eriocaulon henryañum Y12234

Eriocaulon truncatum_CB2757

Eriocaulon nepalense PS353

Eriocaulon cf. nantoeñse HNL0938

Eriocaulon nantoense FS7555

Eriocaulon scariosum Y Y 2310

Eriocaulon scariosum Y12341

- Eriocaulon scariosum Y Y12343

Eriocaulon scariosum YI2345

Eriocaulon buergerianūm YI2237

Eriocaulon cristatum YI2236

Eriocaulon schochiañum TD5050

Eriocaulon cinereum_YI2346 
Fig. 2 (continued)

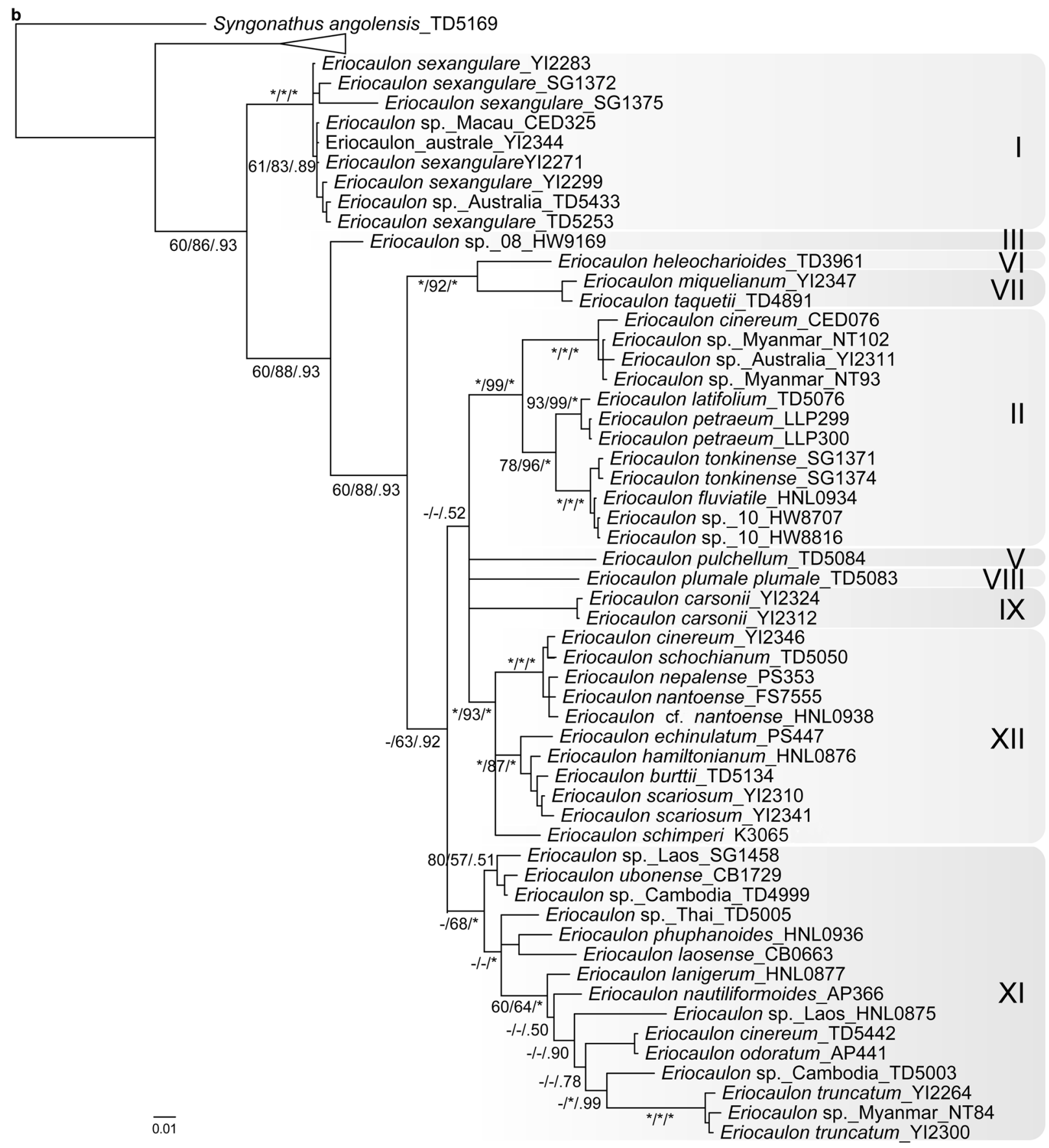

\section{Molecular dating}

The divergence time for each clade was estimated using the calibration point between Eriocaulaceae and Xyridaceae of 105 mya provided by Janssen and Bremer (2004), Bouchenak-Khelladi et al. (2014) and Hertweck et al. (2015). The most recent common ancestor (MRCA) of the Eriocaulaceae family was estimated as early Paleogene with the Eriocauloideae MRCA as mid-Paleogene. The approximate divergence time for the MRCA of Eriocaulon was estimated as late Paleogene to early Neogene (21.66 mya; 95\% HDP = 15.88-28.36 mya) (Fig. 3). Most of the species diversity of Eriocaulon appears to have originated in the the last 10 mya (Fig. 3). 


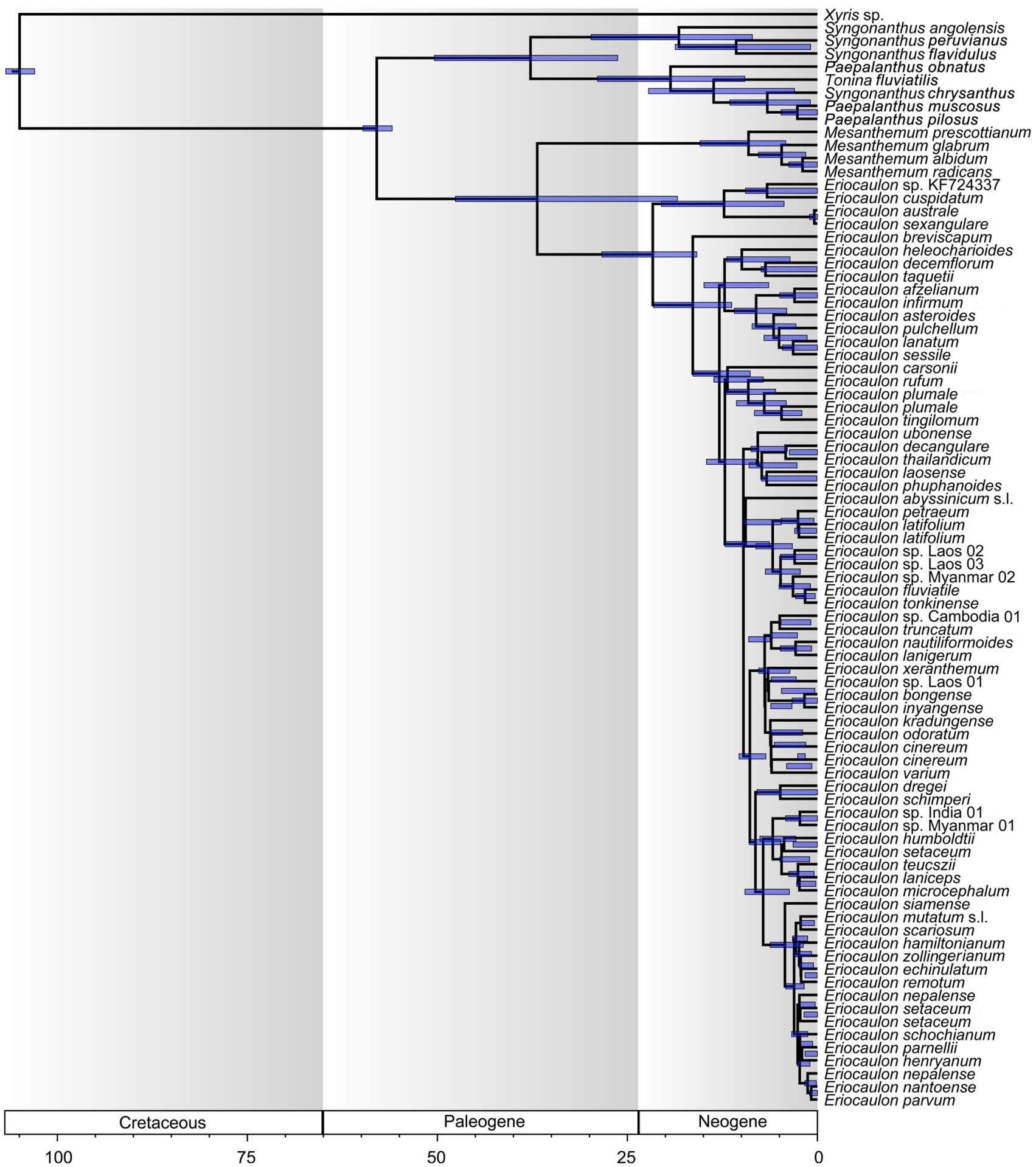

Fig. 3 BEAST maximum clade credibility tree for Eriocaulon obtained from plastid DNA (matK, $r b c \mathrm{~L}, r p o \mathrm{~B}$ and $r p o \mathrm{C} 1)$ and nuclear PHYC sequence data. Clade depth and bars indicate mean nodal ages (mya) and $95 \%$ highest posterior density intervals 


\section{Discussion}

\section{Phylogeny and systematics of Eriocaulon}

We reconstructed the phylogenetic history of Eriocaulon using both ptDNA and PHYC datasets with the aim of assessing the existing regional infrageneric classifications (Table S1). Although our taxon sampling is not sufficiently comprehensive to cover Mueller's (1859) sectional classification for Australian species of Eriocaulon, selected species listed in the infrageneric classifications proposed by Fyson (1919, 1921, 1922), Ma (1991, 1997), Ansari and Balakrishnan $(1994,2009)$ and Zhang (1999) were sampled (Table S1, S2). Here, using the ptDNA tree (Fig. 2a), we discuss whether and how the results support these infrageneric classifications of as well as the previous molecular phylogeny of de Andrade et al. (2010). There is little congruence between our molecular results and previous morphology-based infrageneric classifications. However, some similarities can be found, as detailed below.

In de Andrade et al. (2010) ptDNA tree, Eriocaulon cinereum was retrieved as sister to the other four species including $E$. decangulare L. Our ptDNA tree recovered a similar topology in which $E$. cinereum of clade II branches off before E. decangulare of clade IV (Fig. 2a). Eriocaulon cinereum belongs to sect. Leucantherae Fyson characterised by pale anthers and a smooth seed coat (Fyson 1919, 1921, 1922; Zhang 1999), and recognised by Ansari and Balakrishnan (1994, 2009) as their sect. XII. This group is represented by clade II of the ptDNA tree (Fig. 2a), and hence upheld by both morphological and molecular evidence.

Ma $(1991,1997)$ classified Chinese Eriocaulon into subgen. Trimeranthus of 27 species and subgen. Eriocaulon accommodating E. decemflorum. Although neither subgen. Trimeranthus nor most of its sections or series are supported in our results, it is noteworthy that E. decemflorum is retrieved as a single species lineage (Fig. 2a clade $\mathrm{X}$ ). It was also placed as the only member of sect. Nasmythia by Zhang (1999) based on its dimerous flowers and seed coat structure.

Ansari and Balakrishnan $(1994,2009)$ proposed an infrageneric classification of the Indian species of Eriocaulon into twelve sections, primarily based on seed surface structure. These are mostly not supported by our molecular analysis. For instance, E. nepalense, E. parviflorum (Fyson) R. Ansari \& N.P. Balakr. and E. xeranthemum Mart. are grouped in their sect. III, but are scattered in clades I, XI and XII of the ptDNA tree (Fig. 2a). Similarly, E. truncatum and $E$. hamiltonianum and are grouped in their sect. VII but are here placed in clades XI and XII, respectively (Fig. 2a).

Zhang (1999) carried out a morphology-based cladistic analysis of the 71 East Asian species studied. The resulting cladograms divided the species into four groups. None of these groups are supported in our ptDNA and PHYC trees (Fig. 2). However, noteworthy in our results is the sister relationship between clade I and the rest of Eriocaulon (Fig. 2). Clade I accommodates relatively robust and large species, i.e. E. australe R.Br., E. cuspidatum Dalzell and E. sexangulare L. Zhang (1999) placed E. australe and E. sexangulare in sect. Heterochiton Ruhland. Still, clades II-XII contain morphologically similar species, such as E. rufum Lecomte, E. schimperi Körn. ex Ruhland and $E$. ubonense Lecomte.

\section{Species distribution and taxonomy}

Some species of Eriocaulon are known to have a wide distribution in the Old World tropics, such as E. cinereum and E. setaceum (Cook 1996, 2004). In the present study, E. cinereum is divided into two lineages, one from Africa and the other from Asia, although both fall within clade II (Fig. 2a). Similarly, samples of E. setaceum from Africa and Asia showed genetic variation (Fig. 2a clade XII). On the other hand, no significant differentiations are observed among samples of E. truncatum from Africa and Asia (Fig. 2a clade XI). Species such as E. cinereum and E. truncatum are common in rice fields (Cook 1996), probably contributing to their widespread distribution around the world.

Clade I includes a subclade of 12 accessions of Eriocaulon australe and E. sexangulare. Prajaksood et al. (2012) reduced $E$. australe to a variety of $E$. sexangulare (E. sexangulare var. australe (R.Br.) Praj. \& J.Parn.). These taxa differ in E. australe having hairy leaves, sheaths, involucral bracts and receptable (Prajaksood et al. 2012; Zhang 1999). From our results it appears that this character may not be phylogenetically informative, and therefore, the varietal status of E. australe is supported.

Clade VII comprises Eriocaulon alpestre Hook.f. \& Thomson ex Körn., E. buergerianum Körn., E. sikokianum Maxim., E. hondoense, E. miquelianum and E. taquetii with limited genetic variation among samples (Fig. 2 clade VII). This clade corresponds to subgen. Spathopeplus sect. Apoda of Zhang (1999), a mainly Asian group of species with female sepals connate into a spathe and seeds with T-shaped projections. Our results reflect the taxonomic complexity of this group in Japan, e.g. E. sikokianum Maxim. (accepted name: E. miquelianum Körn.) and E. hondoense (accepted name: E. taquetii Lecomte), while E. buergerianum TCMK_493_K needs critical re-identification because this species is clearly diagnosed by floral morphology (Ma et al. 2000; Miyamoto 2015). Similarly, samples from Africa in clade XII show no clear-cut phylogenetic difference based on the markers used in this study: E. burttii S.M.Phillips, $E$. crassiusculum Lye, E. deightonii Meikle, E. maronderanum S.M. Phillips, E. mutatum N.E. Br, E. nigericum Meikle, 
E. porembskii S.M. Phillips \& Mesterházy, E. remotum Lecomte and E. transvaalicum N.E. Br. However, these species are all distinguishable morphologically by floral structure and seed coat patterning (e.g. Phillips 1998, 2010, 2011). Further phylogenetic work is required to investigate the morphology-based hypotheses for species delimitation in Asian and African species of Eriocaulon.

Several of the 20 samples of Eriocaulon from Cambodia are phylogenetically unique and distinguished from other known species in both ptDNA and PHYC trees (Fig. 2). An in-depth morphological analysis may reveal whether the collections belong to undescribed species.

\section{Evolutionary history of Eriocaulon}

Our results show that Eriocaulon originated in the late Paleogene to early Neogene (Fig. 3), and most species diversity originated in the last 10 mya. With Eriocaulon occurring in (permanent or ephemeral) wetlands across the tropics, the increased speciation during this time may be due to drift arising from fragmentation of suitable habitats associated with aridification since mid-Miocene. During the same period, Poales lineages like Cyperaceae and Poaceae that evolved adaptation to aridification (e.g. C4 photosynthesis, growing in non-wetland habitats) exhibited increased diversification (Bouchenak-Khelladi et al. 2014).

\section{Future perspectives}

For the time being, we refrain from suggesting a new infrageneric classification of this polymorphic and widespread genus until the morphological characters used in previous studies (e.g. seed surface structure, anther colour, floral structure; Ansari and Balakrishnan 1994, 2009; Zhang 1999) can be thoroughly investigated for their phylogenetic informativeness. Further phylogenetic studies, particularly focusing on less well sampled regions such as the Neotropics, will help provide a more global overview of the relationships in Eriocaulon and may enable suggesting the first global infrageneric classification. Further research may also aid towards understanding closely related species groups in Africa and Asia. This study should be seen as a step towards achieving the aim of a natural classification.

Acknowledgements Research by I. Larridon is supported by the B. A. Krukoff Fund for the Study of African Botany. The Royal Botanic Garden Edinburgh (RBGE) is supported by the Scottish Government's Rural and Environmental Science and Analytical Services Division. A grant for this work was provided to RWJ through the Australian Biological Resources Study (ABRS) National Taxonomy Research Grant Programme (RG18-06). This study was supported by the Environment Research and Technology Development Fund (S9) of the Ministry of the Environment, Japan and by a JSPS grant from the Global Center of Excellence Program 'Asian Conservation Ecology as a basis of human-nature mutualism'. Collection and identification of Thai specimens by A. Prajaksood were supported by Office of the Higher Education Commission, The Thailand Research Fund, Khon Kaen University (MRG5480249) and Trinity College Dublin. We acknowledge curators who allowed sampling of tissues from herbarium specimens (PRE). P. Souladeth was supported by a Darwin Fellowship.

Open Access This article is distributed under the terms of the Creative Commons Attribution 4.0 International License (http://creativeco mmons.org/licenses/by/4.0/), which permits unrestricted use, distribution, and reproduction in any medium, provided you give appropriate credit to the original author(s) and the source, provide a link to the Creative Commons license, and indicate if changes were made.

\section{References}

Ansari R, Balakrishnan NP (1994) Family Eriocaulaceae in India. Bishen Singh Mahendra Pal Singh, Dehra Dun

Ansari R, Balakrishnan NP (2009) Family Eriocaulaceae in India, 2nd edn. Bishen Singh Mahendra Pal Singh, Dehra Dun

Bentham G (1878) Eriocaulon. In: Bentham G, von Mueller F (eds) Flora Australiensis 7. Cambridge University Press, Cambridge

Bouchenak-Khelladi Y, Muasya AM, Linder HP (2014) A revised evolutionary history of Poales: origins and diversification. Bot J Linn Soc 175:4-16

Cook CD (1996) Aquatic and wetland plants of India: a reference book and identification manual for the vascular plants found in permanent or seasonal fresh water in the subcontinent of India south of the Himalayas, vol 198548214. Oxford University Press, Oxford

Cook CD (2004) Aquatic and wetland plants of southern Africa: an identification manual for the stoneworts (Charophytina), liverworts (Marchantiopsida), mosses (Bryopsida), quillworts (Lycopodiopsida), ferns (Polypodiopsida) and flowering plants (Magnoliopsida) which grow in water and wetlands of Namibia, Botswana, Swaziland, Lesotho and Republic of South Africa. Backhuys, Leiden

Cuénoud P, Savolainen V, Chatrou LW, Powell M, Grayer RJ, Chase MW (2002) Molecular phylogenetics of Caryophyllales based on nuclear $18 \mathrm{~S}$ rDNA and plastid $r b c L$, atpB, and $m a t K$ DNA sequences. Am J Bot 89:132-144

de Andrade MJ, Giulietti AM, Rapini A, de Queiroz LP, Conceição $\mathrm{AD}$, de Almeida PR, van den Berg C (2010) A comprehensive phylogenetic analysis of Eriocaulaceae: evidence from nuclear (ITS) and plastid ( $p s b \mathrm{~A}-t r n \mathrm{H}$ and $t r n \mathrm{~L}-\mathrm{F})$ DNA sequences. Taxon 59:379-388

Drummond AJ, Rambaut A (2007) BEAST: Bayesian evolutionary analysis by sampling trees. BMC Evol Biol 7:214

Drummond AJ, Ho SY, Phillips MJ, Rambaut A (2006) Relaxed phylogenetics and dating with confidence. PLoS Biol 4:e88

Felsenstein J (1985) Confidence limits on phylogenies: an approach using the bootstrap. Evolution 39:783-791

Fyson PF (1919) The Indian species of Eriocaulon. J Indian Bot $1: 51-55$

Fyson PF (1921) The Indian species of Eriocaulon. J Indian Bot 2:133150 (192-207, 259-266, 307-320)

Fyson PF (1922) The Indian species of Eriocaulon. J Indian Bot 3(12-18):91-115

Giulietti AM, Andrade MJG, Scatena VL, Trovó M, Coan AI, Sano PT, Santos FAR, Borges RLB, van den Berg C (2012) Molecular phylogeny, morphology and their implications for the taxonomy of Eriocaulaceae. Rodriguésia 63:1-19

Heled J, Drummond AJ (2009) Bayesian inference of species trees from multilocus data. Mol Biol Evol 27:570-580 
Hertweck KL, Kinney MS, Stuart SA, Maurin O, Mathews S, Chase MW, Gandolfo MA, Pires JC (2015) Phylogenetics, divergence times and diversification from three genomic partitions in monocots. Bot J Linn Soc 178:375-393

Ito I, Ohi-Toma T, Murata J, Tanaka N (2010) Hybridization and polyploidy of an aquatic plant, Ruppia (Ruppiaceae), inferred from plastid and nuclear DNA phylogenies. Am J Bot 97:1156-1167

Janssen T, Bremer K (2004) The age of major monocot groups inferred from $800+r b c L$ sequences. Bot J Linn Soc 146:385-398

Katoh K, Standley DM (2013) MAFFT multiple sequence alignment software version 7: improvements in performance and usability. Mol Biol Evol 30:772-780

Leach GJ (1992) Eriocaulaceae. In: Wheeler JR (ed) Flora of the Kimberley Region. Department of Conservation and Land Management, Como, pp 1026-1035

Leach GJ (2000) Notes and new species of Eriocaulon (Eriocaulaceae) from Australia. Aust Syst Bot 13:755-772

Leach GJ (2017) A revision of Australian Eriocaulon (Eriocaulaceae). Telopea 20:205-259

Liang Y, Phillips S, Cheek M, Larridon I (2019) Revision of African genus Mesanthemum (Eriocaulaceae). Kew Bulletin (in press)

Little DP, Barrington DS (2003) Major evolutionary events in the origin and diversification of the fern genus Polystichum (Dryopteridaceae). Am J Bot 90:508-514

Ma W (1991) New materials of Eriocaulon L. from China. Acta Phytotax Sin 29:289-314

Ma W (1997) Eriocaulaceae. In: Kuo-fang W (ed) Flora Reipublicae Popularis Sinicae 13(3). Science Press, Beijing, pp 20-63

Ma WL, Zhang Z, Stútzel T (2000) Eriocaulaceae. In: Flora of China, vol 24, pp 7-17. http://flora.huh.harvard.edu/china/mss/volum e24/ERIOCAULACEAE.published.pdf. Accessed 15 June 2019

Mathews S, Donoghue MJ (1999) The root of angiosperm phylogeny inferred from duplicate phytochrome genes. Science 286:947-950

Meikle RD (1968) Notes on the Eriocaulaceae of West Tropical Africa. Kew Bull 22:141-144

Miller MA, Pfeiffer W, Schwartz T (2010) Creating the CIPRES Science Gateway for inference of large phylogenetic trees. In: Proceedings of the gateway computing environments workshop (GCE), 14 November 2010, New Orleans, LA, pp 1-8

Miyamoto F (2015) Eriocaulaceae. In: Ohashi H, Kadota Y, Murata J, Yonekura K, Kihara H (eds) Wild flowers of Japan, vol 1. Cycadaceae-Cyperaceae, Heibonsha, Tokyo, pp 280-286 (in Japanese)

Mueller FJH (1859) Fragmenta Phytographiae Australiae 1:91-96

Nylander JA (2002) MrModeltest v1. 0b. Program distributed by the author. Department of Systematic Zoology, Uppsala University, Uppsala

Phillips SM (1998) Flora of Tropical East Africa, Eriocaulaceae edn. Ed. Polhill. Balkema, Rotterdam

Phillips SM (2010) Flora Zambesiaca Vol.13(4): 33-86. Eriocaulaceae. Royal Botanic Gardens, Kew

Phillips SM (2011) Flore du Cameroun 38. Eriocaulaceae. Ministry of Scientific Research and Innovation, Yaoundé

Phillips SM, van der Burgt XM, Kanu KM (2012) Two new species of Eriocaulon (Eriocaulaceae) from Sierra Leone. Kew Bull $67: 273-280$
Prajaksood A, Parnell JAN, Chantaranothai P (2012) New taxa and new combinations of Eriocaulaceae from Thailand. Kew Bulletin 67:655-685

Prajaksood A, Chantaranothai P, Parnell JAN (2017) Eriocaulaceae. In: Santisuk T, Balslev H (eds) Flora of Thailand 13(3):434-511 The Forest Herbarium. National Park, Wildlife and Plant Conservation Department, Bangkok

Rambaut A (2009) FigTree, version 1.3. 1. Computer program distributed by the author. http://www.treebioedacuk/software/figtr ee. Accessed 4 Jan 2011

Rambaut A, Drummond AJ, Suchard M (2014) Tracer v1. 6. http:// beast.bio.ed.ac.uk. Accessed 8 Sept 2018

Ronquist F, Huelsenbeck JP (2003) MrBayes 3: Bayesian phylogenetic inference under mixed models. Bioinformatics 19:1572-1574

Ronquist F, Teslenko M, Van Der Mark P, Ayres DL, Darling A, Höhna S, Larget B, Liu L, Suchard MA, Huelsenbeck JP (2012) MrBayes 3.2: efficient Bayesian phylogenetic inference and model choice across a large model space. Syst Biol 61:539-542

Ruhland W (1903) Eriocaulaceae. In: Engler A (ed) Das Pflanzenreich IV, vol 30. Engelmann, Leipzig, pp 301-394

Samuel R, Kathriarachchi H, Hoffmann P, Barfuss MH, Wurdack KJ, Davis CC, Chase MW (2005) Molecular phylogenetics of Phyllanthaceae: evidence from plastid $\mathrm{matK}$ and nuclear PHYC sequences. Am J Bot 92:132-141

Stamatakis A (2006) RAxML-VI-HPC: maximum likelihood-based phylogenetic analyses with thousands of taxa and mixed models. Bioinformatics 22:2688-2690

Stamatakis A, Hoover P, Rougemont J (2008) A rapid bootstrap algorithm for the RAxML web servers. Syst Biol 57:758-771

Stützel T (1998) Eriocaulaceae. In: Kubitzki K (ed) Families and genera of vascular plants 4. Springer, Berlin, pp 197-207

Swofford DL (2002) PAUP phylogenetic analysis using parsimony (and other methods), Version 4.0 Beta 10. Sinauer Associates, Sunderland

WCSP (2019) World checklist of selected plant families. Facilitated by the Royal Botanic Gardens, Kew. http://wcsp.science.kew.org/. Accessed 2 May 2019

Whitten WM, Williams NH, Chase MW (2000) Subtribal and generic relationships of Maxillarieae (Orchidaceae) with emphasis on Stanhopeinae: combined molecular evidence. Am J Bot 87:1842-1856

Wolf PG, Soltis PS, Soltis DE (1994) Phylogenetic relationships of dennstaedtioid ferns: evidence from $r b c \mathrm{~L}$ sequences. Mol Phyl Evol 3:383-392

Yang Z, Rannala B (1997) Bayesian phylogenetic inference using DNA sequences: a Markov Chain Monte Carlo method. Mol Biol Evol 14:717-724

Zhang Z (1999) Monographie der Gattung Eriocaulon in Ostasien. Dissertationes Botanicae, Band 313

Publisher's Note Springer Nature remains neutral with regard to jurisdictional claims in published maps and institutional affiliations. 


\section{Affiliations}

Isabel Larridon ${ }^{1}\left(\right.$ Norio Tanaka $^{2} \cdot$ Yuxi Liang ${ }^{1} \cdot$ Sylvia M. Phillips ${ }^{1} \cdot$ Anders S. Barfod $^{3}$. Seong-Hyun Cho $^{4}$. Stephan W. Gale ${ }^{5} \cdot$ Richard W. Jobson $^{6} \cdot$ Young-Dong Kim $^{4} \cdot$ Jie Li $^{7} \cdot$ A. Muthama Muasya ${ }^{8} \cdot$ John A. N. Parnell $^{9}$. Amornrat Prajaksood ${ }^{10} \cdot$ Kohtaroh Shutoh $^{11} \cdot$ Phetlasy Souladeth $^{12} \cdot$ Shuichiro Tagane $^{13} \cdot$ Nobuyuki Tanaka $^{2}$. Okihito Yano ${ }^{14} \cdot$ Attila Mesterházy $^{15} \cdot$ Mark F. Newman $^{16} \cdot$ Yu $^{\text {Ito }}{ }^{17}$

1 Royal Botanic Gardens, Kew, Richmond, Surrey TW9 3AE, UK

2 Department of Botany, National Museum of Nature and Science, 4-1-1 Amakubo, Tsukuba, Ibaraki 305-0005, Japan

3 Department of Bioscience, Aarhus University, Ny Munkegade 114, 8000 Aarhus C, Denmark

4 Multidisciplinary Genome Institute, Hallym University, Chuncheon 24252, Korea

5 Kadoorie Farm and Botanic Garden, Lam Kam Road, Tai Po, New Territories, Hong Kong, SAR, China

6 National Herbarium of New South Wales, Royal Botanic Gardens and Domain Trust, Mrs Macquaries Road, Sydney, NSW 2000, Australia

7 Xishuangbanna Tropical Botanical Garden, Plant Phylogenetics and Conservation Group, Chinese Academy of Sciences, Kunming 650223, China

8 Department of Biological Sciences, University of Cape Town, Bolus Herbarium, Private Bag X3, Rondebosch 7701, South Africa

9 Herbarium, Botany Department, Trinity College Dublin, Dublin 2, Ireland
10 Department of Biology, Faculty of Science, Khon Kaen University, Khon Kaen 40002, Thailand

11 The Hokkaido University Museum, Hokkaido University, Kita 10, Nishi 8, Kita-ku, Sapporo, Hokkaido 060-0810, Japan

12 National University of Laos, Dongdok Campus, Xaythany District, Vientiane Capital, Lao PDR

13 The Kagoshima University Museum, Kagoshima University, 1-21-30 Korimoto, Kagoshima 890-0065, Japan

14 Department of Biosphere-Geosphere Science, Faculty of Biosphere-Geosphere Science, Okayama University of Science, Ridai-cho 1-1, Kita-ku, Okayama, Okayama 700-0005, Japan

15 Directory of Hortobágy National Park, Sumen utca 2, Debrecen 4024, Hungary

16 Royal Botanic Garden Edinburgh, 20A Inverleith Row, Edinburgh, Scotland EH3 5LR, UK

17 Faculty of Pharmaceutical Sciences, Setsunan University, Osaka, Japan 